\title{
Corporate Sustainability: First Evidence on Materiality
}

\section{Citation}

Khan, Mozaffar N., George Serafeim, and Aaron Yoon. "Corporate Sustainability: First Evidence on Materiality." Harvard Business School Working Paper, No. 15-073, March 2015.

\section{Permanent link}

http://nrs.harvard.edu/urn-3:HUL.InstRepos:14369106

\section{Terms of Use}

This article was downloaded from Harvard University's DASH repository, and is made available under the terms and conditions applicable to Open Access Policy Articles, as set forth at http:// nrs.harvard.edu/urn-3:HUL.InstRepos:dash.current.terms-of-use\#OAP

\section{Share Your Story}

The Harvard community has made this article openly available.

Please share how this access benefits you. Submit a story.

\section{Accessibility}




\section{Corporate Sustainability: First Evidence on Materiality}

Mozaffar Khan

George Serafeim

Aaron Yoon

Working Paper 15-073 


\title{
Corporate Sustainability: First Evidence on Materiality
}

\author{
Mozaffar Khan \\ Harvard Business School \\ George Serafeim \\ Harvard Business School
}

Aaron Yoon

Harvard Business School

Working Paper 15-073 


\title{
Corporate Sustainability: First Evidence on Materiality
}

\author{
Mozaffar Khan, George Serafeim, and Aaron Yoon*
}

\begin{abstract}
An increasing number of companies make sustainability investments, and an increasing number of investors integrate sustainability performance data in their capital allocation decisions. To date however, the prior academic literature has not distinguished between investments in material versus immaterial sustainability issues. We develop a novel dataset by hand-mapping data on sustainability investments classified as material for each industry into firm-specific performance data on a variety of sustainability investments. This allows us to present new evidence on the value implications of sustainability investments. Using calendar-time portfolio stock return regressions we find that firms with good performance on material sustainability issues significantly outperform firms with poor performance on these issues, suggesting that investments in sustainability issues are shareholder-value enhancing. Further, firms with good performance on sustainability issues not classified as material do not underperform firms with poor performance on these same issues, suggesting investments in sustainability issues are at a minimum not value-destroying. Finally, firms with good performance on material issues and concurrently poor performance on immaterial issues perform the best. These results speak to the efficiency of firms' sustainability investments, and also have implications for asset managers who have committed to the integration of sustainability factors in their capital allocation decisions.
\end{abstract}

\footnotetext{
${ }^{*}$ Mozaffar Khan is a visiting Associate Professor at Harvard Business School. George Serafeim is the Jakurski Family Associate Professor of Business Administration at Harvard Business School. Aaron Yoon is a doctoral student at Harvard Business School. We are grateful for comments from seminar participants at National University of Singapore and Harvard Business School. We are grateful for financial support from the Division of Faculty Research and Development at Harvard Business School. George Serafeim has served on the Standards Council of SASB. Contact emails: mkhan@hbs.edu; gserafeim@hbs.edu; ayoon@hbs.edu.
} 


\section{Introduction}

Corporate investment policies are a key determinant of firm value and continue to be widely studied in the literature. Multiple studies have investigated different types of investments and how these relate to future financial performance. A relatively newer class of corporate investments, broadly termed sustainability investments, has attracted the attention of firms, institutional investors, academics, and societal advocacy groups. Are such corporate investments ultimately value-enhancing for shareholders? A number of studies have investigated this question but the results remain mixed. One potential reason for the mixed results is that no prior paper has distinguished between sustainability issues that are material for a company versus all other less material sustainability issues (which we refer to as "immaterial" throughout the rest of the paper). Investments in immaterial issues are less likely than investments in material issues to be value-enhancing, and it therefore becomes important in testing the value implications of such sustainability investments to distinguish between investments in material versus immaterial issues. We respond to this gap in the literature.

A large number of companies now identify sustainability issues as strategically important and release a wealth of information in the form of environmental, social and governance (ESG) data. However, the materiality of the reported sustainability investments for firm value is regularly questioned, with companies releasing an increasing amount of information that might be immaterial from an investment standpoint. ${ }^{1}$ Similarly, an increasing number of investors commit to the integration of ESG data in their capital allocation process, but which of these ESG data should be taken into consideration is still a point of tension.

The importance of the different sustainability issues likely varies systematically across firms and industries (Eccles and Serafeim 2013). ${ }^{2}$ As such, the efforts of many organizations providing guidance on

\footnotetext{
${ }^{1}$ See for example http://www.corporatesecretary.com/articles/compliance-ethics-csr/12425/sasb-previewssustainability-standards-financials/

${ }^{2}$ See for example United Nations Environment Program Finance Initiative and World Business Council for Sustainable Development. 2010. Translating environmental, social and governance factors into sustainable business value http://www.unepfi.org/fileadmin/documents/translatingESG.pdf.
} 
reporting of ESG issues (for example, the International Integrated Reporting Council, the Global Reporting Initiative, and the Sustainability Accounting Standards Board (SASB)) are now concentrated on identifying material issues by industry in order to guide both company disclosure and investor integration of sustainability data in asset allocation decisions.

We develop a unique and novel data set to measure firm performance on material sustainability issues by hand-mapping recently-available industry-specific guidance on materiality from SASB to MSCI KLD that has firm-level performance ratings on an array of sustainability issues. Section 3 describes the data and mapping in detail. We then construct a materiality (immateriality) performance score for each firm-year that measures performance on material (immaterial) sustainability issues in order to test the shareholder value implications of sustainability investments.

To test the future performance implications of sustainability investments we first orthogonalize a firm's change in materiality score with respect to changes in firm size, market-to-book ratio, leverage, profitability, and sector membership. Next, we form portfolios based on the unexplained portion of the materiality score change (the residuals from the first step) and estimate Fama and French (1993) calendartime regressions to test for one-year-ahead abnormal stock return performance of the portfolio. This procedure allows us to attribute the future performance of this portfolio more confidently to material sustainability investments, rather than to underlying firm characteristics of portfolio firms.

Results indicate that firms with strong performance on material topics outperform firms with poor performance on material topics, consistent with material investments being shareholder value-enhancing. In contrast, firms with strong performance on immaterial sustainability topics do not outperform firms with poor performance on immaterial topics, indicating sustainability investments are at a minimum not shareholder value-destroying. Finally, firms with high materiality scores and concurrently low immateriality scores have the best future stock performance, as expected. A series of additional tests indicate that the results are robust to alternative factor models, different subsamples, and alternative portfolio construction rules. Moreover, we find that firms with strong performance on material topics 
exhibit better future changes in accounting performance compared to firms with poor performance on material topics

The results contribute to a large literature that investigates the relation between sustainability and financial performance (Margolis et al. 2007; Eccles et al. 2014). The results from this line of research still remain mixed and a number of explanations have been suggested for the mixed results. We show that firms can engage both in material and immaterial sustainability issues and the two actions have different implications for stock prices. Failure to distinguish between the two can produce an insignificant relation between performance on sustainability issues and future financial performance. The results are also likely to be of interest to firms making sustainability investment decisions, and to investors making portfolio allocation decisions based in any part on sustainability criteria.

The rest of the paper proceeds as follows. Section 2 describes the motivation and literature review. Section 3 presents our sample and data. Section 4 discusses the results from our research design. Section 5 concludes.

\section{Motivation and Literature Review}

An increasing number of investors have also committed to integrating sustainability issues in their asset allocation decisions and an increasing number of companies have been disclosing sustainability information. Specifically, the number of companies issuing sustainability reports has grown from less than 30 in early 1990s to more than 7,000 in 2014, while the United Nations Principles for Responsible Investment (UNPRI), as of 2014, had 1,260 signatories with \$45 trillion in assets under management. These signatories commit to six principles 'recognizing the materiality of environmental, social, and governance issues. ${ }^{3}$ Therefore, given the number of companies that now disclose sustainability information and the size of the committed assets under management, understanding the investment relevance of sustainability issues is an important topic.

\footnotetext{
${ }^{3}$ See http://www.unpri.org/about-pri/about-pri/
} 
Scholars within the neoclassical economics tradition have argued theoretically that sustainability investments unnecessarily raise a firm's costs, thus creating a competitive disadvantage vis-à-vis competitors (Friedman, 1970; Aupperle et al., 1985; McWilliams and Siegel, 1997; Jensen, 2002). Arguing from an agency theory perspective (Jensen and Meckling, 1976), other studies have suggested that employing valuable firm resources for positive social performance strategies results in significant managerial benefits rather than financial benefits to shareholders (Brammer and Millington, 2008).

Cheng, Hong and Shue (2014) find support for an agency motive for corporate social responsibility. They use the 2003 Dividend Tax Cut to increase after-tax insider ownership and find that after the tax cut firms with moderate levels of insider ownership have lower sustainability performance compared to firms with low levels (where the tax cut has no effect) and high levels (where agency is less of an issue). De Giuli and Kostovetsky (2014) find that social responsibility investments are motivated by political beliefs and that these sustainability investments driven by political beliefs are value destroying for shareholders.

On the other hand, scholars have argued that enhanced sustainability performance may lead to obtaining better resources (Cochran and Wood, 1984; Waddock and Graves, 1997), higher quality employees (Turban and Greening, 1997), and better marketing of products and services (Moskowitz, 1972; Fombrun, 1996). Better sustainability performance may also function in similar ways as advertising does, by increasing overall demand for products and services or by reducing consumer price sensitivity (Dorfman and Steiner, 1954; Navarro, 1988; Sen and Bhattacharya, 2001; Milgrom and Roberts, 1986). Moreover, it has been suggested that positive social performance could reduce the level of waste within productive processes (Konar and Cohen, 2001; Porter and Van Der Linde, 1995). Stakeholder theory emphasizes that effective management of stakeholder relationships may mitigate the likelihood of negative regulatory, legislative or fiscal action (Freeman, 1984; Berman et al., 1999; Hillman and Keim, 2001), while protecting and enhancing corporate reputation (Fombrun and Shanley, 1990; Fombrun, 2005; Freeman et al., 2007). 
Eccles et al. (2014) identify a set of U.S. firms that adopted corporate policies related to environmental and social issues before the adoption of such policies became widespread. They match those firms to competitors with similar financial performance, size, capital structure and valuation and find that firms that adopted the sustainability policies outperform their peers over the long-term, both in terms of stock market and accounting performance. Borgers et al. (2013) find that firms with better sustainability performance have higher risk-adjusted returns in the future but that in more recent years firms with better sustainability performance have lower alphas. Consistent with the claim that improving sustainability performance leads to better financial performance, Dimson, Karakas and Li (2014) show that after successful engagements, particularly on environmental/social issues, companies experience improved accounting performance and governance, and increased institutional ownership. However, all of the studies that have used KLD and more generally sustainability data so far (e.g. Derwall, Koedijk, and Ter Horst 2011; Galema, Plantinga, and Scholtens 2008) have not differentiated sustainability factors to material and immaterial.

\section{Data and Sample}

\subsection{Data on Materiality}

Our data collection is driven by the availability of materiality guidance from SASB. SASB is an independent 501(c)3 non-profit. SASB's mission is to develop and disseminate sustainability accounting standards that help publicly-listed corporations disclose material factors in compliance with SEC requirements. Through these standards, along with associated education and outreach, SASB is working to increase the usefulness of information available to investors, and improve corporate performance on the environmental, social, and governance issues most likely to impact value. SASB standards are designed for the disclosure of material sustainability issues in mandatory SEC filings, such as the Form 10-K and 20-F. SASB is accredited to establish sustainability accounting standards by the American National Standards Institute (ANSI). Accreditation by ANSI signifies that SASB's procedures to develop 
SASB sustainability accounting standards meet the Institute's requirements for openness, balance, consensus and due process.

By February 2014, SASB had produced guidance for six sectors (out of a total of 10) that include 45 industries. These sectors were healthcare, financials, technology and communications, non-renewable resources, transportation, and services. SASB's standards are developed via a multi-stakeholder process consisting of research supported by Bloomberg technology, data and analytical tools; balanced, multistakeholder industry working groups; a public comment period; and review by an independent Standards Council comprised of experts in standards development, securities law, environmental law, metrics and accounting. Appendix I illustrates each step of the standard setting process. SASB convenes balanced industry working groups-consisting of $1 / 3$ corporations, $1 / 3$ market participants, and $1 / 3$ other stakeholders - to provide feedback on SASB's draft sustainability accounting standards. For the four sectors mentioned above, more than 2,100 experts representing \$21.7 trillion in assets under management and \$9.7 trillion in company market capitalization had participated in SASB's industry working groups.

For each topic, SASB conducts an evidence of materiality test, informed by staff research and industry working groups, the results of which ultimately are debated and reviewed by the Standards Council after industry working groups composed of industry experts have provided their input. The test has three components: evidence of interest, evidence of financial impact, and forward impact adjustment. We describe each one in more detail in Appendix II but the interested reader can find more information on the SASB website.

\subsection{Sustainability Data}

We use MSCI KLD as our source of sustainability data, the most widely used dataset by past studies. For the purposes of this paper, KLD has a number of advantages. First, it includes a large number of U.S. companies over a long period of time. In particular, between 1991 and 2000 it included approximately 650 companies, 2001-2002 1,100 companies, and 2003-2012 3,000 companies. Other databases with sustainability data have both shorter time-series and they cover fewer U.S. companies. For example, 
Thomson Reuters ASSET4 starts data coverage in 2002 and it includes anywhere between 300-900 U.S. companies throughout that period. Another advantage of the KLD data is that it provides information about performance on a specific issue in a standardized format rather than the presence or absence of disclosure, as it is the case for many data items in ASSET4 or Bloomberg.

KLD data have been widely used in the literature by researchers examining the relation between social responsibility and financial performance (e.g., Graves \& Waddock, 1994; Turban \& Greening, 1997; Fisman, Heal, \& Nair, 2005; Mattingly \& Berman, 2006; Godfrey, Merrill, \& Hansen, 2009; Ioannou and Serafeim 2014). Researchers at KLD review the company's public documents, including the annual report, the company website, corporate social responsibility reporting, and other stakeholders' and data sources. Company ratings represent a snapshot of the firm's profile at calendar year end. KLD researchers also monitor media sources for developing issues on a daily basis. The KLD dataset is compiled around the beginning of every year (i.e. January) and it is typically available in spreadsheets for distribution at the latest by late February.

The KLD historical ratings data set is designed as a binary system and comprises both strengths and concerns. Strengths represent policies, procedures, and outcomes that enable a firm to have a positive impact on the focal issue. Concerns represent policies, procedures, and outcomes that tend to have a negative impact on the focal issue. For each strength or concern rating applied to a company, KLD includes a "1" indicating the presence of that screen/criterion and a "0" indicating its absence. In total, seven issue areas are included: a) Community, b) Corporate Governance, c) Diversity, d) Employee Relations, e) Product, f) Environment, and g) Human Rights. Within each issue area, multiple topics and respective data items exist. For example, under the Environment issue area, KLD tracks performance on waste management, packaging materials and waste, environmental opportunities, climate change, and water stress, among other issues. Under the Social issues area, KLD tracks performance on community engagement, human rights, union relations, workforce diversity, and access to finance, among other issues. Under Governance issues area, KLD tracks performance on issues including reporting quality, corruption and political instability, financial system instability, governance structure, and business ethics. 
Table 1 Panel A shows how we arrive at the final sample from the original KLD dataset. Panel B shows the number of unique firms and unique firm-years that are covered by KLD and included in our sample. The sample comprises 647 firms from the financial, 547 from the healthcare, 341 from the nonrenewable resources, 283 from the services, 369 from the technology and communications, and 120 from the transportation sector. In total there are 2,307 unique firms and 13,397 unique firm-years included in our sample. Firms are allocated to sectors and industries according to the Bloomberg Industrial Classification System (BICS). BICS is the industrial classification system used by SASB and it is the standard system used by investments banks and money management firms. ${ }^{4}$ Panel $\mathrm{C}$ shows the frequency of firms in our sample by year, which, as expected, increases over time. For these firms, we analyze their sustainability performance and identify good and poor performers.

\subsection{Construction of the Materiality Index}

To classify each KLD data item to material or immaterial, we follow guidance from SASB for each one of the 45 industries in our sample. Specifically, we download each industry standard that identifies material sustainability issues for companies within an industry. To classify topics, one researcher takes the lead in one sector and all the industries included in that sector. Each topic identified by SASB as material is mapped to a KLD item, when one is available. After having a complete mapping, another researcher follows the same process. The two mappings are then compared by a third researcher, who assesses any differences. In our case, differences in mappings across researchers were minimal as the mapping process in most cases was relatively straightforward. ${ }^{5}$

All KLD data items that were mapped to SASB items were classified as material. All the remaining KLD data items were classified as immaterial. Appendix III shows the materiality map of SASB at the sector level. A more granular view at the industry level can be obtained by visiting the SASB

\footnotetext{
${ }^{4}$ SASB's industrial classification system is powered by the Bloomberg Industry Classification System. SASB leverages the Bloomberg Industry Classification System to identify which industry companies are assigned to.

${ }^{5}$ The two researchers disagreed on $2 \%$ of the total number of mappings. These differences were resolved by consultation with the third researcher.
} 
website. Industries within a sector generally had similar issues classified as material but differences could be found. Approximately $55 \%$ of all possible sector-issue pairs were either material or immaterial for all industries within the sector (Appendix III). The largest variability across industries within a sector is in the services sector where only $20 \%$ of the issues were either material or immaterial across all industries. The lowest variability is within the financials and technology and communication sectors with more than $67 \%$. The total number of material items identified is small compared to the total number of KLD data items, which is 109 , consistent with SASB claims that their guidance narrows significantly the number of issues that a firm needs to disclose. The number of material data items ranges from 13 for the healthcare sector to 32 for services sector while the financials, transportation, and the nonrenewable resources sector have 22 and the technology and communications sector has 19 data items that are material. Broadly speaking for the nonrenewable resources and transportation sectors environmental issues dominate, while for the financial sector governance and product related issues tend to represent most of the material issues. For the healthcare, services, and the technology and communications sectors social issues represent a large number of the material issues. Appendix III provides more detailed information and for industry mappings the interested reader can visit the SASB website.

To construct a materiality and immateriality index for firm $i$ in year $t$, we follow the practice, common in the literature, of subtracting the concerns from the strengths to arrive at a single net score (e.g., Graves and Waddock, 1994; Griffin and Mahon, 1997; Waddock and Graves, 1997; Johnson and Greening, 1999; Ruf et al., 2001; Ioannou and Serafeim, 2014):

Material $_{\mathrm{it}}=\sum K L D$ STRENGTH it, SASB $-\sum K L D$ CONCERN it, SASB

Immaterial $_{\text {it }}=\sum K L D$ STRENGTH it, NONSASB $-\sum K L D$ CONCERN it, NONSASB

Panel B of Table 1 shows the number of firms each year with a materiality score and an immateriality score. These are the firms available each year to form portfolios as described next.

\subsection{Portfolio Formation and Estimation}


To test the future performance implications of firms' sustainability performance, we begin by orthogonalizing changes in the materiality score with respect to changes in firm size, market-to-book ratio (MTB), profitability (ROA), financial leverage, and sector fixed effects $\left(\mathrm{f}_{\mathrm{s}}\right)$ cross-sectionally each year as follows: $:^{6,7}$

$\Delta$ Material $_{\text {it }}=\mathrm{b}_{1}+\mathrm{b}_{2} \Delta$ Size $_{i t}+\mathrm{b}_{3} \Delta \mathrm{MTB}_{\mathrm{it}}+\mathrm{b}_{4} \Delta \mathrm{ROA}_{\mathrm{it}}+\mathrm{b}_{5} \Delta$ Leverage $_{\mathrm{it}}+\mathrm{f}_{\mathrm{s}}+\mathrm{e}_{\mathrm{i}, \mathrm{t}}$

$\Delta$ Immaterial $_{\text {it }}=\mathrm{b}_{6}+\mathrm{b}_{7} \Delta$ Size $_{\mathrm{it}}+\mathrm{b}_{8} \Delta \mathrm{MTB}_{\mathrm{it}}+\mathrm{b}_{9} \Delta \mathrm{ROA}_{\mathrm{it}}+\mathrm{b}_{10} \Delta$ Leverage $_{\mathrm{it}}+\mathrm{f}_{\mathrm{s}}+\mathrm{u}_{\mathrm{i}, \mathrm{t}}$

The signals used to construct portfolios are the residuals from equations (3) and (4), which are unexplained changes in the materiality and immateriality scores (hereafter "Materiality" and "Immateriality"). This procedure is intended to mitigate concerns about correlated firm characteristics potentially confounding inferences about the future performance implications of the materiality score. Moreover, by using for each firm the change in the material or immateriality score, we attempt to isolate the unexpected level of sustainability investments.

The Materiality portfolios are constructed each year by assigning firms with a Materiality score at the top (bottom) quintile in that year to the top (bottom) portfolio. Results are robust to constructing the top and bottom portfolios as the top and bottom deciles or quartiles of Materiality. The Immateriality portfolios are constructed in the same manner.

The KLD data are released by the end of February each year, and financial statement data needed for estimation of equation (3) are available for almost all firms by the end of March, so we construct portfolios at the end of March to allow an implementable trading strategy. Value-weighted and equalweighted portfolios are held from the beginning of April until the end of March of the following year. Abnormal stock return performance of the portfolios is estimated from Fama and French (1993) monthly

\footnotetext{
${ }^{6}$ We regress on those variables because they are fundamental characteristics of a firm in terms of size, growth opportunities and valuation, financial structure, and profitability. In untabulated results, we added past stock return and earnings volatility, accruals, and dividend yield, but none of the estimated coefficients on those variables was significant and the explanatory power of the model was unchanged.

${ }^{7}$ Substituting sector for industry fixed effects produces very similar results and does not raise the explanatory power of the model. While sustainability performance seems to vary across sectors it varies to a less significant extent across industries within a sector. Moreover, in the early period of the sample, the number of industries is large enough that the average number of companies within an industry is small.
} 
calendar-time regressions that include the market, size, book-to-market, momentum (Carhart, 1997), and liquidity (Pastor and Stambaugh, 2003) factors.

Table 2, Panels A and B, present summary statistics for our sample and the Compustat universe, respectively. As expected and consistent with prior studies using KLD data our sample includes larger firms, with higher price to book ratios and profitability margins, and higher institutional ownership. Panel C presents summary statistics for the level of the materiality and immateriality indices as well as for all the variables used to estimate models 3 and 4. Panel D presents univariate correlations between the variables used in the analysis. The correlation between the materiality and immateriality scores is positive and moderate (0.3). This suggests that different types of investments are related but are sufficiently different to allow us to differentiate firms. The material index exhibits small positive correlations with both MTB (0.08) and size (0.03) and a small negative correlation with leverage (-0.02). The immaterial index exhibits small positive correlations with both MTB (0.05) and ROA (0.08) and a moderate correlation with size (0.28). The residuals derived from models 3 and 4 exhibit much lower correlation between them (0.13), compared to the 0.30 of the raw indices, and they have nearly zero correlation with all MTB, ROA, size and leverage.

\section{Results}

\section{Materiality Index and Stock Returns}

Table 3 presents the estimated coefficients of a five-factor model for the bottom quintile, quartile, and decile portfolios and top quintile, quartile, and decile portfolios of performance on material sustainability issues. Panel A presents results for value-weighted portfolios, and Panel B presents results for equalweighted portfolios. The estimated alpha for the top portfolio is significant $(p$-value $<0.05)$ in all specifications in Panels A and B of Table 3, ranging from about 3\% to about $8 \%$ annualized. We find stronger results as we construct portfolios that maximize the difference in material scores with the decile results producing a larger difference in alphas compared to the quintile and those compared to the quartile portfolios. The value-weighted alphas are slightly higher than equal-weighted alphas for equivalent 
specifications in Panels A and B. The estimated alphas for the bottom portfolio are insignificant in all specifications in Panel A, and in two of the three specifications in Panel B. Collectively the results in Table 3 indicate that investments in sustainability issues are value-enhancing for shareholders.

Table 4 presents robustness tests. First we assess the robustness of results to different factor models. We estimate alphas using the Fama-French (1993) three-factor model that excludes the momentum and liquidity factors, or a four-factor model that excludes the liquidity factor (Carhart 1997). The results are unchanged using these alternative factor models. We find a $3.84 \%$ and $3.98 \%$ outperformance on a three- and four-factor model respectively using value-weighted portfolios. The outperformance is $2.84 \%$ and $3.67 \%$ on a three- and four-factor model respectively using equal-weighted portfolios.

The second robustness test excludes firms with business involvement in controversial businesses. Past literature documents that 'sin' stocks outperform in the future because they have been neglected by the market (Hong and Kacperczyk 2009). Because the involvement in 'sin' business could be directly related to sustainability scores, we assess the robustness of our results excluding firms that participate in such lines of business. Although the industries included in our sample do not involve 'sin' businesses, some of the companies might still have ties to 'sin' businesses through equity ownerships or alliances. KLD provides data on business involvement in the alcohol, firearms, gambling, military, and tobacco businesses. These stocks are just $4 \%$ of the entire sample and we exclude them from our portfolios. As expected, for the industries in our sample, not that many companies are involved in sin businesses. Therefore, our results are very similar. The outperformance is $5.58 \%$ and $3.83 \%$ on a value- and equalweighted basis respectively.

Across almost all specifications estimated, we find a larger difference in performance across the two groups of firms for value-weighted portfolios, consistent with studies that document sustainability issues to have a larger impact on larger firms. For example, Eccles, Ioannou and Serafeim (2014) show that firms adopting sustainability policies in the early 1990s, before adoption of such policies became common, outperformed their matched peers by $2.4 \%$ on an equal-weighted basis but by $4.7 \%$ on a value- 
weighted basis. A more significant impact on larger firms could be attributed to large firms being more visible and thereby more vulnerable to reputation risk, political and regulatory risk, under more scrutiny by NGOs, and more likely to be targeted by consumer campaigns (McWilliams and Siegel, 2001; Campbell 2007). Also, firm size seems to be an important explanatory variable of a firm's commitment to sustainability issues and a firm's disclosure practices around those issues (Ioannou and Serafeim 2012).

\section{Immateriality Index and Stock Returns}

Table 5 shows results when one ranks firms on immaterial sustainability issues and using quintile portfolios. For the sake of brevity we do not report quartile or decile regressions but inferences remain unchanged. Specifically, a portfolio of firms scoring high on immaterial issues underperforms a portfolio of firms scoring low by $-1.49 \%$ on an equal weighted base. A portfolio of firms scoring high on immaterial issues outperforms a portfolio of firms scoring low by $0.71 \%$ a year on a value-weighted base. None of the estimated alphas is statistically significant. This suggests that the immateriality index does not distinguish between firms and thereby is not able to predict future stock market performance.

Table 5, Panel B presents robustness tests. We again assess the robustness of our results to different factor models. Results are unchanged when we use these alternative factor models. We find that portfolio of firms scoring high on immaterial issues does not exhibit different performance compared to a portfolio of firms exhibit scoring low on immaterial issues. Moreover, on an equal-weighted basis we find that firms scoring high have lower alphas across all specifications although again the estimates are not significant.

\section{Materiality Index, Immateriality Index and Stock Returns}

So far we have compared firms with superior performance on material sustainability issues versus companies with inferior performance on those issues. To shed more light on the differential return on investment from material versus immaterial sustainability issues, we compare firms with good performance on material issues and bad performance on immaterial issues ('Material investment firms') 
versus firms with good performance on immaterial issues and bad performance on material issues ('Immaterial investment firms'). This allows us to provide sharper evidence on the shareholder value implications of sustainability investments.

We use quartile portfolios as cutoff values both for bad and good performance as requiring quintile or decile portfolios results in very few stocks in portfolios due to the positive univariate correlation between material and immaterial scores. However, quartile portfolio cutoffs yield weaker results overall so the results in this section should be benchmarked against that backdrop. Imposing a quartile cutoff for the portfolio results in approximately 35 stocks on average every year in each one of the portfolios for Material and Immaterial investment firms. The number of stocks in the All and No investment firms is closer to on average 50 every year. This makes sense given the positive correlation between the material and the immaterial index. The number of firms that exhibit high performance on one index and low performance on the other is lower compared to firms that perform good or bad on both.

Table 6 presents the estimated coefficients of a five-factor model for value-weighted portfolios. The estimated alpha for the portfolio of Material investment firms is larger in magnitude and statistically different from zero. We find estimated alphas of 6.01 and $0.60 \%$ for top performers on material issues and immaterial issues for a difference of $5.41 \%$ annually. The difference is significant at the $1 \%$ level. Material investment firms also outperform All investment firms by $4.05 \%$. This result shows the importance of firms distinguishing between the types of investments they make. Grouping both material and immaterial investments together yields lower performance. Firms that make no investments have the worst performance across all groups of firms with an estimated alpha of $-2.90 \%$. The results are similar using equal-weighted instead of value-weighted portfolios. Comparing the alphas on the set of firms with good performance on material sustainability suggests that the positive effect from investments in material sustainability issues are larger for firms that make investments only in material sustainability issues versus firms that make investments on both material and immaterial issues.

\section{Future Accounting Performance}


Until this point we have examined future stock market performance to understand the value implications of sustainability investments. We complement this analysis by examining future changes in accounting performance. The number of investors integrating ESG data in investment decisions has grown considerably over the period of study potentially putting price pressure on the stocks of firms with good ESG performance and contributing to the positive alphas found earlier for firms with good sustainability performance. If firms investing in material sustainability issues exhibit superior future accounting performance then one can infer that price pressure alone cannot explain the superior future stock price performance though.

Table 7 shows future changes in accounting performance of firms scoring high and low on the materiality index for quintile portfolios. Firms performing better on material sustainability issues experience relatively more positive changes in profitability margins. Specifically, we find that changes in return-on-sales (ROS) and sales growth are more positive for the portfolio of firms performing better on material issues. We tabulate changes in ROS and sales growth up to three years in the future because after that the number of observations declines. Across all time horizons the difference in future changes in profitability margins is positive for both ROS and sales growth. We find similar patterns when we examine changes in ROA, and return-on-equity. These results are consistent with prior literature that suggests that sustainability investments can lead to brand building, competitive differentiation and operating efficiency (Sen and Bhattacharya, 2001; Konar and Cohen, 2001; Freeman et al., 2007).

\section{Conclusion}

We use recent guidance by an accounting standard setter, namely the Sustainability Accounting Standards Board (SASB) to classify sustainability topics to material or immaterial according to industry membership. We find that firms with superior performance on material sustainability issues outperform firms with inferior performance on material sustainability issues in the future.

Our results represent a way to reconcile conflicting evidence in the literature. First, a large part of the literature that has attempted to document a relation between ratings of sustainability performance and 
future financial performance has largely failed to find any strong results (Margolis et al. 2014). We argue that this is, at least partly, because the literature has failed to distinguish between material and immaterial sustainability issues. The results in this paper are also likely to be of interest to firms making sustainability investment decisions, and to investors making portfolio allocation decisions based in any part on sustainability criteria. Overall, this is paper is the first to show that investments in material sustainability issues can be value-enhancing for shareholders while investments in immaterial sustainability issues have little positive or negative, if any, value implications.

Moreover, our results suggest that recent accounting standard setting efforts for nonfinancial information are successful in separating material from less material information for investment purposes. A fruitful area for future research would be examining why firms choose to make different types of investments as well as why and how firms choose to make different types of disclosures. 


\section{References}

Berman, S. L., Wicks, A. C., Kotha, S., \& Jones, T. M. 1999. Does stakeholder orientation matter? The relationship between stakeholder management models and firm financial performance. The Academy of Management Journal, 42(5): 488-506.

Blair, Margaret M. and Stout, Lynn A. 1999. A Team Production Theory of Corporate Law. Virginia Law Review, Vol. 85, No. 2: 248-328.

Borgers, A., Derwall, J., Koedijk, K., \& Ter Horst, J. 2013. Stakeholder relations and stock returns: on errors in investors' expectations and learning. Journal of Empirical Finance 22: 159-175.

Derwall, J., Koedjk, K, and Ter Horst, J. 2011. A tale of values-driven and profit-seeking social investors. Journal of Banking and Finance 35: 2137-2147.

Di Giuli, A. and Kostovetsky, L. 2014. Are red or blue companies more likely to go green? Politics and corporate social responsibility. Journal of Financial Economics, vol. 111, issue 1: 158-180

Eccles, R., \& G., Serafeim. 2013. The Performance Frontier: Innovating for a Sustainable Strategy. Harvard Business Review 91, no. 5: 50-60.

Eccles, R., Ioannou I., and Serafeim G. 2014. The Impact of Corporate Sustainability on Organizational Processes and Performance. Management Science 60, no. 11: 2835-2857.

Fombrun, C. \& Shanley, M. 1990. What's in a name? Reputation building and corporate strategy. Academy of management Journal: 233-258.

Freeman, R. 1984. Strategic Management: A stakeholder perspective. Boston, MA: Piman.

Freeman, R. E., Harrison, J. S., \& Wicks, A. C. 2007. Managing for stakeholders: survival, reputation, and success. New Haven, CT: Yale Univ Press.

Friedman, M. 1970. The social responsibility of business is to increase its profits. New York Times Magazine, 32(13): 122-126.

Galema, R., Plantinga, A., and Scholtens, B. 2008. The stocks at stake: return and risk in socially responsible investment. Journal of Banking and Finance 32: 2646-2654.

Godfrey, P. C., Merrill, C. B., \& Hansen, J. M. 2009. The relationship between corporate social responsibility and shareholder value: an empirical test of the risk management hypothesis. Strategic Management Journal, 30(4): 425-445.

Graves, S. B. \& Waddock, S. A. 1994. Institutional owners and corporate social performance. The Academy of Management Journal, 37(4): 1034-1046.

Guerard Jr, J. B. 1997. Additional evidence on the cost of being socially responsible in investing. The Journal of Investing, 6(4): 31-36.

Guerard Jr, J. B. 1997. Is there a cost to being socially responsible in investing? The Journal of Investing, 6(2): 11-18. 
Hart, S. L. 1995. A natural-resource-based view of the firm. Academy of Management Review: 986-1014.

Hillman, A. J. \& Keim, G. D. 2001. Shareholder value, stakeholder management, and social issues: what's the bottom line? Strategic Management Journal, 22(2): 125-139.

Hong, H. \& M Kacperczyk. 2009. The price of sin: The effects of social norms on markets. Journal of Financial Economics, 93 (1): 15-36.

Ioannou, Ioannis, and George Serafeim. 2012. What Drives Corporate Social Performance? The Role of Nation-level Institutions. Journal of International Business Studies 43, no. 9: 834-864.

Jensen, M. C. \& Meckling, W. H. 1976. Theory of the firm: managerial behavior, agency costs and ownership structure. Journal of Financial Economics, 3(4): 305-360.

Jensen, M. C. 2002. Value maximization, stakeholder theory, and the corporate objective function. Business Ethics Quarterly, 12(2): 235-256.

Konar, S. \& Cohen, M. A. 2001. Does the market value environmental performance? Review of Economics and Statistics, 83(2): 281-289.

Luo, X. \& Bhattacharya, C. B. 2006. Corporate social responsibility, customer satisfaction, and market value. Journal of Marketing, 70(4): 1-18.

Margolis, J. D. \& Walsh, J. P. 2003. Misery loves companies: rethinking social initiatives by business. Administrative Science Quarterly, 48(2): 268-305.

McWilliams, A. \& Siegel, D. 1997. The Role of Money Managers in Assessing Corporate Social Reponsibility Research. The Journal of Investing, 6(4): 98-107.

McWilliams, A. \& Siegel, D. 2000. Corporate social responsibility and financial performance: correlation or misspecification? Strategic Management Journal, 21(5): 603-609.

Milgrom, P. \& Roberts, J. 1986. Price and advertising signals of product quality. The Journal of Political Economy, 94(4): 796. $71-75$.

Moskowitz, M. 1972. Choosing socially responsible stocks. Business and Society Review, 1(1):

Navarro, P. 1988. Why do corporations give to charity? The Journal of Business, 61(1): 65-93.

Orlitzky, M., Schmidt, F. L., \& Rynes, S. L. 2003. Corporate social and financial performance: A meta-analysis. Organization Studies, 24(3): 403-441.

Porter, M. E. \& Van der Linde, C. 1995. Toward a new conception of the environmentcompetitiveness relationship. The Journal of Economic Perspectives: 97-118.

Sen, S. \& Bhattacharya, C. B. 2001. Does doing good always lead to doing better? Consumer reactions to corporate social responsibility. Journal of Marketing Research, 38(2): 225-243.

Siegel, D. \& Vitaliano, D. F. 2007. An empirical analysis of the strategic use of corporate social 
responsibility. Journal of Economics \& Management Strategy, 16(3): 773-792.

Turban, D. B. \& Greening, D. W. 1997. Corporate social performance and organizational attractiveness to prospective employees. The Academy of Management Journal, 40(3): 658-672. 
Table 1

Panel A: Sample Construction

\begin{tabular}{lrr}
\hline & \# of firms & \# of firm-years \\
\hline KLD Data (From 1991 to 2012) & 6,161 & 38,063 \\
Less: sectors not covered by SASB yet & $(3,280)$ & $(21,097)$ \\
Less: missing firm fundamentals (COMPUSTAT/CRSP items) & $(65)$ & $(595)$ \\
Less: deletion from changes specification & $(509)$ & $(2,974)$ \\
\hline Total & $\mathbf{2 , 3 0 7}$ & $\mathbf{1 3 , 3 9 7}$ \\
\hline
\end{tabular}

Panel B: Frequency by Sector

\begin{tabular}{lll}
\hline Sector & \# unique firms & \# of firm-years \\
\hline Financial & 647 & 3,874 \\
Healthcare & 547 & 2,958 \\
Non-renewable Resources & 341 & 2,140 \\
Services & 283 & 1,696 \\
Technology and Communication & 369 & 1,914 \\
Transportation & 120 & 815 \\
\hline Total & 2,307 & 13,397 \\
\hline
\end{tabular}

Panel C: Frequency by year

\begin{tabular}{cccc}
\hline Year & \# of firms & Year & \# of firms \\
\hline 1992 & 195 & 2003 & 459 \\
1993 & 196 & 2004 & 1,104 \\
1994 & 193 & 2005 & 1,148 \\
1995 & 157 & 2006 & 1,133 \\
1996 & 184 & 2007 & 1,112 \\
1997 & 182 & 2008 & 1,197 \\
1998 & 183 & 2009 & 1,244 \\
1999 & 192 & 2010 & 1,226 \\
2000 & 190 & 2011 & 1,297 \\
2001 & 212 & 2012 & 1,217 \\
2002 & 376 & & \\
\hline
\end{tabular}




\section{Table 2}

Panel A: Summary Statistics for the Sample in this Study

\begin{tabular}{lrrrrrr}
\hline & \multicolumn{1}{c}{ Mean } & Median & \multicolumn{1}{c}{ St Dev. } & \multicolumn{1}{c}{ Q1 } & Q3 & $\mathrm{N}$ \\
\hline ROA & 0.02 & 0.03 & 0.12 & 0.01 & 0.07 & 13,397 \\
Leverage & 0.57 & 0.57 & 0.25 & 0.38 & 0.81 & 13,397 \\
Price to Book & 1.18 & 1.08 & 0.53 & 0.80 & 1.45 & 13,397 \\
Market Cap & 6516.52 & 1290.25 & 16021.98 & 446.99 & 4195.01 & 13,397
\end{tabular}

Panel B: Summary Statistics for the Compustat Universe

\begin{tabular}{lrrrrrr}
\hline & \multicolumn{1}{c}{ Mean } & \multicolumn{1}{c}{ Median } & \multicolumn{1}{c}{ St Dev. } & \multicolumn{1}{c}{ Q1 } & \multicolumn{1}{c}{ Q3 } & N \\
\hline ROA & -0.17 & 0.01 & 0.74 & -0.09 & 0.06 & 211,007 \\
Leverage & 0.75 & 0.56 & 1.29 & 0.32 & 0.80 & 210,321 \\
Price to Book & 1.09 & 0.97 & 0.69 & 0.67 & 1.40 & 182,239 \\
Market Cap & 1987.85 & 128.01 & 6670.73 & 24.08 & 753.99 & 191,466
\end{tabular}

Panel C: Summary Statistics for Sustainability Scores and Firm Characteristics

\begin{tabular}{lccc}
\hline & Mean & St Dev. & $\mathrm{N}$ \\
\hline Material Index & -0.1032 & 0.9050 & 13,397 \\
Immaterial Index & -0.1804 & 1.9530 & 13,397 \\
$\Delta$ Material Index & 0.0317 & 0.6306 & 13,397 \\
$\Delta$ Immaterial Index & 0.0160 & 1.2862 & 13,397 \\
$\Delta$ Size & 0.0339 & 0.4925 & 13,397 \\
$\Delta$ MTB & -0.0321 & 0.3183 & 13,397 \\
$\Delta$ ROA & -0.0014 & 0.1006 & 13,397 \\
$\Delta$ Leverage & 0.0033 & 0.0776 & 13,397 \\
\hline
\end{tabular}


Panel D: Correlation Matrix

\begin{tabular}{lccccc}
\hline & $\begin{array}{c}\text { Material } \\
\text { Index }\end{array}$ & $\begin{array}{c}\text { Immaterial } \\
\text { Index }\end{array}$ & MTB & Size & ROA \\
\hline Immaterial Index & 0.3051 & 1.0000 & & \\
& $<.0001$ & & & & \\
MTB & 0.0867 & 0.0474 & 1.0000 & & \\
& $<.0001$ & $<.0001$ & & & \\
Size & 0.0331 & 0.2776 & 0.2640 & 1.0000 & \\
& 0.0001 & $<.0001$ & $<.0001$ & & \\
ROA & -0.0099 & 0.0837 & 0.0382 & 0.3005 & 1.0000 \\
& 0.2508 & $<.0001$ & $<.0001$ & $<.0001$ & \\
Leverage & -0.0265 & -0.0006 & -0.0587 & 0.0683 & -0.0893 \\
& 0.0021 & 0.9458 & $<.0001$ & $<.0001$ & $<.0001$ \\
\hline
\end{tabular}

Panel A presents summary statistics for our sample and Panel B for the Compustat universe. Panel C presents summary statistics for the sustainability scores and changes in firm measures. Panel D presents a univariate correlation matrix. ROA is income before extraordinary items over the average of total assets of the current and previous year. Leverage is long-term debt plus current debt over the average of total assets of the current and previous year. MTB is market value at the end of the calendar year over book value of equity. Market Cap is the market capitalization at the end of the calendar year. Size is the natural logarithm of the market capitalization at the end of the calendar year. Institutional ownership is the percentage of shares outstanding held by institutional investors. 
Table 3

Panel A: Performance on Material Sustainability Issues- Value Weighted

\begin{tabular}{|c|c|c|c|c|c|c|c|c|c|c|c|c|}
\hline \multirow[b]{3}{*}{ Parameter } & \multicolumn{2}{|c|}{ Low Performance } & \multirow{2}{*}{\multicolumn{2}{|c|}{$\begin{array}{l}\text { High Performance } \\
\text { tile }\end{array}$}} & \multicolumn{2}{|c|}{ Low Performance } & \multicolumn{2}{|c|}{ High Performance } & \multicolumn{2}{|c|}{ Low Performance } & \multicolumn{2}{|c|}{ High Performance } \\
\hline & \multicolumn{2}{|c|}{ Quintile } & & & \multicolumn{4}{|c|}{ Quartile } & \multicolumn{4}{|c|}{ Decile } \\
\hline & Estimate & $\mathrm{t}$ & Estimate & $\mathrm{t}$ & Estimate & $\mathrm{t}$ & Estimate & $\mathrm{t}$ & Estimate & $\mathrm{t}$ & Estimate & $\mathrm{t}$ \\
\hline Intercept & -0.0013 & -0.79 & 0.0028 & 2.04 & -0.0001 & -0.08 & 0.0023 & 1.92 & -0.0028 & -1.59 & 0.0045 & 2.63 \\
\hline Market & 1.0933 & 23.03 & 0.9415 & 27.59 & 1.0953 & 25.15 & 0.9504 & 31.32 & 1.0919 & 21.01 & 0.9515 & 22.40 \\
\hline SMB & -0.2007 & -2.34 & -0.2337 & -4.19 & -0.2099 & -2.91 & -0.2261 & -4.54 & -0.2681 & -3.28 & -0.2306 & -3.67 \\
\hline HML & -0.0738 & -0.88 & 0.1136 & 2.02 & -0.0832 & -1.13 & 0.1270 & 2.51 & 0.0403 & 0.38 & 0.0627 & 1.00 \\
\hline UMD & -0.0163 & -0.29 & -0.0163 & -0.39 & -0.0239 & -0.49 & -0.0495 & -1.40 & -0.0513 & -0.96 & -0.1166 & -2.00 \\
\hline LIQ & 0.1299 & 2.80 & 0.0837 & 1.93 & 0.1145 & 2.71 & 0.0700 & 1.89 & 0.1996 & 3.83 & 0.0770 & 1.54 \\
\hline $\mathrm{N}$ & 249 & & 249 & & 249 & & 249 & & 249 & & 249 & \\
\hline Annualized Alpha & $-1.59 \%$ & & $3.39 \%$ & & $-0.15 \%$ & & $2.85 \%$ & & $-3.30 \%$ & & $5.56 \%$ & \\
\hline Difference in Alphas & & & $4.98 \% * *$ & & & & $3.00 \% *$ & & & & $8.85 \% * * *$ & \\
\hline
\end{tabular}


Panel B: Performance on Material Sustainability Issues- Equal Weighted

\begin{tabular}{|c|c|c|c|c|c|c|c|c|c|c|c|c|}
\hline \multirow[b]{3}{*}{ Parameter } & \multicolumn{2}{|c|}{ Low Performance } & \multicolumn{2}{|c|}{ High Performance } & \multicolumn{2}{|c|}{ Low Performance } & \multicolumn{2}{|c|}{ High Performance } & \multicolumn{2}{|c|}{ Low Performance } & \multicolumn{2}{|c|}{ High Performance } \\
\hline & \multicolumn{4}{|c|}{ Quintile } & \multicolumn{4}{|c|}{ Quartile } & \multicolumn{4}{|c|}{ Decile } \\
\hline & Estimate & $\mathrm{t}$ & Estimate & $\mathrm{t}$ & Estimate & $\mathrm{t}$ & Estimate & $\mathrm{t}$ & Estimate & $\mathrm{t}$ & Estimate & $\mathrm{t}$ \\
\hline Intercept & 0.0015 & 1.37 & 0.0043 & 2.65 & 0.0023 & 1.98 & 0.0035 & 2.20 & 0.0018 & 1.18 & 0.0047 & 2.71 \\
\hline Market & 1.0735 & 37.32 & 1.0634 & 25.80 & 1.0740 & 36.34 & 1.0661 & 26.90 & 1.0843 & 29.86 & 1.0257 & 25.08 \\
\hline SMB & 0.0942 & 1.72 & 0.2053 & 2.99 & 0.1001 & 1.75 & 0.2260 & 3.37 & 0.1430 & 2.18 & 0.1497 & 2.39 \\
\hline HML & 0.3888 & 8.11 & 0.6555 & 9.13 & 0.3312 & 7.19 & 0.6881 & 9.81 & 0.5656 & 9.17 & 0.5222 & 7.15 \\
\hline UMD & -0.0991 & -3.62 & -0.1831 & -3.11 & -0.1115 & -3.65 & -0.2088 & -3.30 & -0.1277 & -2.61 & -0.1916 & -3.51 \\
\hline LIQ & 0.1110 & 3.82 & 0.1480 & 2.58 & 0.0823 & 2.68 & 0.1253 & 2.37 & 0.1911 & 5.10 & 0.1265 & 2.05 \\
\hline $\mathrm{N}$ & 249 & & 249 & & 249 & & 249 & & 249 & & 249 & \\
\hline Annualized Alpha & $1.86 \%$ & & $5.24 \%$ & & $2.85 \%$ & & $4.29 \%$ & & $2.13 \%$ & & $5.76 \%$ & \\
\hline Difference in Alphas & & & $3.38 \% *$ & & & & $1.44 \%$ & & & & $3.64 \% *$ & \\
\hline
\end{tabular}

Table 4 reports alphas, factor loadings, and t-statistics from monthly calendar-time Fama-French regressions. Panel A (B) reports results for value-weighted (equal-weighted) portfolios. The regressions are estimated over the 249 months from April 1993 to December 2013. Mkt-Rf is the market excess return; SMB and HML are the Fama and French (1993) size and book-to-market factors; UMD is the Carhart (1997) momentum factor; LIQ is the liquidity factor from Pastor and Stambaugh (2003). ***,**, and * indicate one-tailed p-value less than $1,2.5$, and $5 \%$, respectively. 
Table 4

Robustness Tests

\begin{tabular}{|c|c|c|c|c|c|c|}
\hline & Low Performance & High Perform & & \multicolumn{3}{|c|}{ High Performance } \\
\hline & \multicolumn{3}{|c|}{ Value-weighted } & \multicolumn{3}{|c|}{ Equal-weighted } \\
\hline & \multicolumn{2}{|c|}{ Annualized Alpha } & Difference & \multicolumn{2}{|c|}{ Annualized Alpha } & Difference \\
\hline \multicolumn{7}{|l|}{ I. Alternative Factor Models } \\
\hline Raw Return & $6.72 \%$ & $10.97 \%$ & $4.25 \% * *$ & $11.95 \%$ & $16.52 \%$ & $4.57 \% * *$ \\
\hline 3-factor alpha & $-0.84 \%$ & $3.84 \%$ & $4.68 \% * *$ & $1.72 \%$ & $4.56 \%$ & $2.84 \% *$ \\
\hline 4-factor alpha & $-0.71 \%$ & $3.98 \%$ & $4.70 \% * *$ & $2.63 \%$ & $6.30 \%$ & $3.67 \% * *$ \\
\hline II. Excluding 'sin' business & $-1.52 \%$ & $4.06 \%$ & $5.58 \% * * *$ & $1.96 \%$ & $5.78 \%$ & $3.83 \% * *$ \\
\hline
\end{tabular}

The table reports alphas from Fama-French (1993) and Carhart (1997) calendar-time regressions of monthly returns. Sections II and III report alphas from fivefactor models as in Table 3. The regressions are estimated over the 249 months from April 1993 to December $2013 . * * *$, **, and * indicate one-tailed p-value less than $1,2.5$, and $5 \%$, respectively. 
Table 5

Panel A: Performance on Immaterial Sustainability Issues

\begin{tabular}{|c|c|c|c|c|c|c|c|c|}
\hline \multirow[b]{3}{*}{ Parameter } & \multicolumn{2}{|c|}{ Low Performance } & \multicolumn{2}{|c|}{ High Performance } & \multicolumn{2}{|c|}{ Low Performance } & \multicolumn{2}{|c|}{ High Performance } \\
\hline & \multicolumn{4}{|c|}{ Value-weighted } & \multicolumn{4}{|c|}{ Equal-weighted } \\
\hline & Estimate & $\mathrm{t}$ & Estimate & $\mathrm{t}$ & Estimate & $\mathrm{t}$ & Estimate & $\mathrm{t}$ \\
\hline Intercept & 0.0005 & 0.33 & 0.0011 & 0.91 & 0.0033 & 2.64 & 0.0021 & 1.80 \\
\hline Market & 0.9453 & 22.67 & 1.0285 & 34.98 & 1.0461 & 34.83 & 1.0697 & 32.82 \\
\hline SMB & -0.0955 & -1.40 & -0.2033 & -4.32 & 0.2100 & 4.50 & 0.1647 & 2.60 \\
\hline HML & 0.0078 & 0.11 & -0.0043 & -0.08 & 0.4443 & 9.79 & 0.4440 & 9.42 \\
\hline UMD & -0.0765 & -1.28 & -0.0062 & -0.17 & -0.1508 & -5.52 & -0.1804 & -4.77 \\
\hline LIQ & 0.0853 & 2.03 & -0.0657 & -2.03 & 0.0386 & 1.34 & 0.0145 & 0.42 \\
\hline $\mathrm{N}$ & 249 & & 249 & & 249 & & 249 & \\
\hline Annualized Alpha & $0.64 \%$ & & $1.35 \%$ & & $3.99 \%$ & & $2.50 \%$ & \\
\hline Difference in Alphas & & & $0.71 \%$ & & & & $-1.49 \%$ & \\
\hline
\end{tabular}

The table reports alphas, factor loadings, and t-statistics from monthly calendar-time Fama-French regressions. The regressions are estimated over the 249 months from April 1993 to December 2013. Mkt-Rf is the market excess return; SMB and HML are the Fama and French (1993) size and book-to-market factors; UMD is the Carhart (1997) momentum factor; LIQ is the liquidity factor from Pastor and Stambaugh (2003). ***, **, and * indicate one-tailed p-value less than $1,2.5$, and $5 \%$, respectively. 
Panel B: Robustness Tests

\begin{tabular}{|c|c|c|c|c|c|c|}
\hline & Low Performance & High Perforn & & \multicolumn{3}{|c|}{ High Performance } \\
\hline & \multicolumn{3}{|c|}{ Value-weighted } & \multicolumn{3}{|c|}{ Equal-weighted } \\
\hline & \multicolumn{2}{|c|}{ Annualized Alpha } & \multirow[t]{2}{*}{ Difference } & \multicolumn{2}{|c|}{ Annualized Alpha } & Difference \\
\hline \multicolumn{6}{|l|}{ I. Alternative Factor Models } & \\
\hline Raw Return & $7.80 \%$ & $8.13 \%$ & $0.34 \%$ & $13.68 \%$ & $11.73 \%$ & $-1.95 \%$ \\
\hline 3-factor alpha & $0.53 \%$ & $0.82 \%$ & $0.29 \%$ & $2.85 \%$ & $0.93 \%$ & $-1.92 \%$ \\
\hline 4-factor alpha & $1.23 \%$ & $0.89 \%$ & $-0.34 \%$ & $4.27 \%$ & $2.60 \%$ & $-1.67 \%$ \\
\hline II. Excluding 'sin’ business & $0.92 \%$ & $1.79 \%$ & $0.88 \%$ & $4.36 \%$ & $3.05 \%$ & $-1.31 \%$ \\
\hline
\end{tabular}

The table reports in section I alphas from Fama-French (1993) and Carhart (1997) calendar-time regressions of monthly returns. Sections II report alphas from five-factor models as in Table 3. The regressions are estimated over the 249 months from April 1993 to December 2013. ***, **, and * indicate one-tailed pvalue less than $1,2.5$, and $5 \%$, respectively. 
Table 6

Performance on Material and Immaterial Sustainability Issues

\begin{tabular}{|c|c|c|c|c|c|c|c|c|}
\hline \multirow[b]{2}{*}{ Parameter } & \multicolumn{2}{|c|}{$\begin{array}{c}\text { Low Performance } \\
\text { on Immaterial Issues \& } \\
\text { High Performance on } \\
\text { Material }\end{array}$} & \multicolumn{2}{|c|}{$\begin{array}{c}\text { High Performance on } \\
\text { Immaterial Issues \& } \\
\text { Low Performance on } \\
\text { Material }\end{array}$} & \multicolumn{2}{|c|}{$\begin{array}{c}\text { High Performance on } \\
\text { Immaterial Issues \& } \\
\text { High Performance on } \\
\text { Material }\end{array}$} & \multicolumn{2}{|c|}{$\begin{array}{c}\text { Low Performance on } \\
\text { Immaterial Issues \& } \\
\text { Low Performance on } \\
\text { Material }\end{array}$} \\
\hline & Estimate & $\mathrm{t}$ & Estimate & $\mathrm{t}$ & Estimate & $\mathrm{t}$ & Estimate & $\mathrm{t}$ \\
\hline Intercept & 0.0049 & 2.40 & 0.0005 & 0.23 & 0.0016 & 0.70 & -0.0024 & -1.05 \\
\hline Market & 0.8652 & 18.08 & 1.0429 & 17.25 & 0.9558 & 17.98 & 1.0260 & 17.76 \\
\hline SMB & -0.1804 & -2.62 & -0.1546 & -1.69 & -0.1412 & -1.77 & -0.0143 & -0.12 \\
\hline HML & 0.2886 & 3.86 & -0.1210 & -1.02 & -0.0611 & -0.56 & 0.1174 & 1.19 \\
\hline UMD & -0.0376 & -0.73 & -0.0666 & -1.04 & -0.2168 & -2.94 & -0.1503 & -1.99 \\
\hline LIQ & 0.0745 & 1.49 & 0.0231 & 0.31 & 0.0331 & 0.42 & 0.2376 & 3.86 \\
\hline $\mathrm{N}$ & 249 & & 249 & & 249 & & 249 & \\
\hline Annualized Alpha & $6.01 \%$ & & $0.60 \%$ & & $1.96 \%$ & & $-2.90 \%$ & \\
\hline Difference in Alphas & & & $5.41 \% * * *$ & & $4.05 \% * *$ & & $8.90 \% * * *$ & \\
\hline
\end{tabular}

The table reports alphas, factor loadings, and t-statistics from monthly calendar-time Fama-French regressions for value-weighted portfolios. The regressions are estimated over the 249 months from April 1993 to December 2013. Mkt-Rf is the market excess return; SMB and HML are the Fama and French (1993) size and book-to-market factors; UMD is the Carhart (1997) momentum factor; LIQ is the liquidity factor from Pastor and Stambaugh (2003). ***, **, and * indicate onetailed p-value less than $1,2.5$, and $5 \%$, respectively. 
Table 7

Future Accounting Performance

\begin{tabular}{l|ccc} 
ROS Growth & $\mathrm{t}=0$ to $\mathrm{t}=1$ & $\mathrm{t}=0$ to $\mathrm{t}=2$ & $\mathrm{t}=0$ to $\mathrm{t}=3$ \\
\hline Low Performance on Material Issues & $-2.36 \%$ & $-3.32 \%$ & $-6.03 \%$ \\
High Performance on Material Issues & $4.50 \%$ & $3.60 \%$ & $3.09 \%$ \\
Difference & $6.86 \% * *$ & $6.91 \% * *$ & $9.12 \% * *$ \\
& & & \\
Sales Growth & $\mathrm{t}=0$ to $\mathrm{t}=1$ & $\mathrm{t}=0$ to $\mathrm{t}=2$ & $\mathrm{t}=0$ to $\mathrm{t}=3$ \\
\hline Low Performance on Material Issues & $9.74 \%$ & $20.35 \%$ & $30.98 \%$ \\
High Performance on Material Issues & $12.25 \%$ & $22.99 \%$ & $34.64 \%$ \\
Difference & $2.51 \% * *$ & $2.65 \% * *$ & $3.66 \% * *$
\end{tabular}

The table reports changes in return-on-sales (ROS) and sales growth between the year of portfolio formation and future years. ROS is net income over average sales. $\mathrm{t}=\mathrm{x}$ to $\mathrm{t}=\mathrm{y}$ represents a change between year $\mathrm{x}$ and year $\mathrm{y} . * *, * *$, and $*$ indicate one-tailed $\mathrm{p}$-value less than $1,2.5$, and $5 \%$, respectively. 
Appendix I

SASB's Standard Setting Process

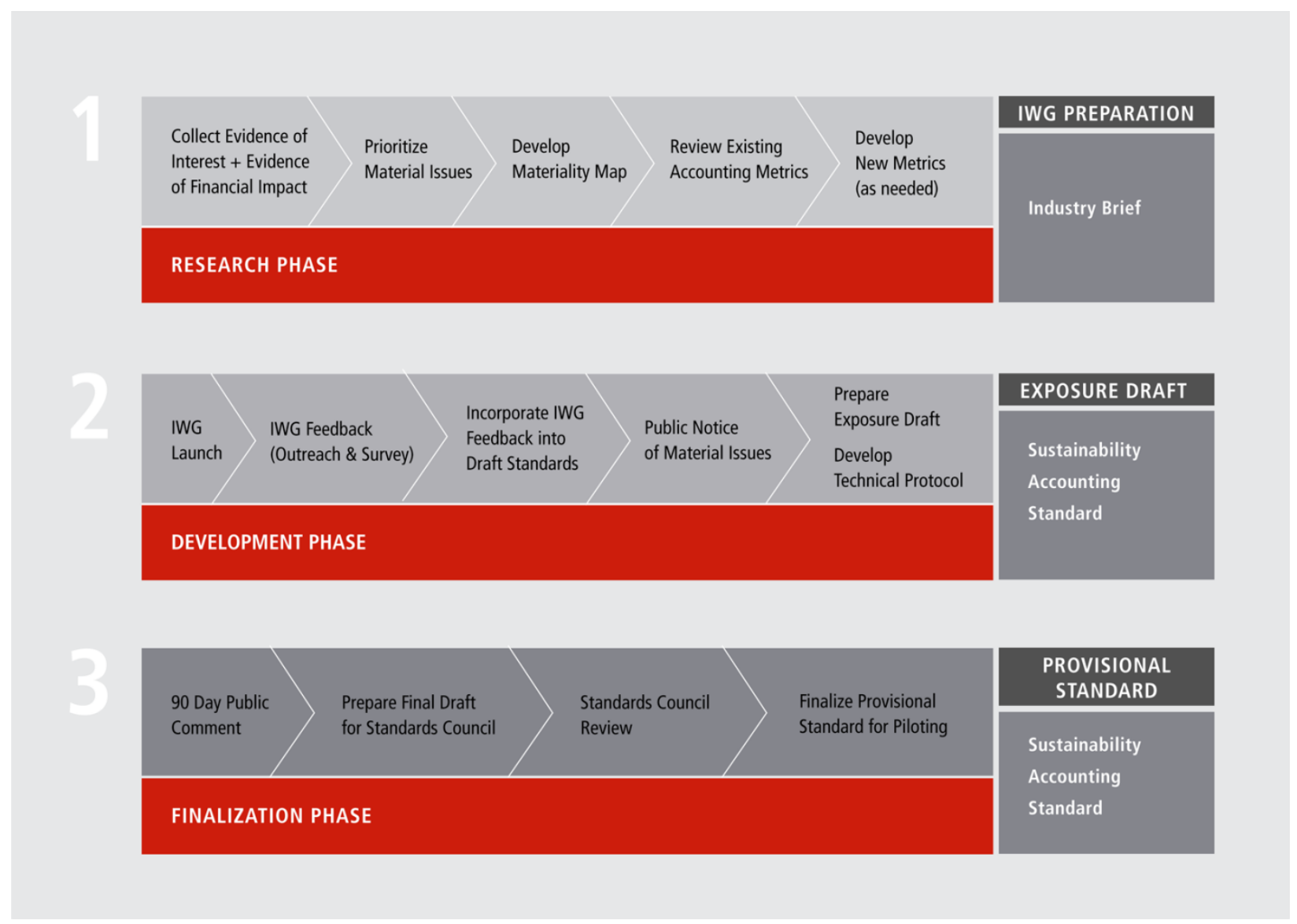

Source: Sustainability Accounting Standards Board. www.sasb.org 


\section{Appendix II}

\section{SASB's Materiality Process}

For each topic, SASB conducts an evidence of materiality test, the results of which ultimately are debated and reviewed by the Standards Council after industry working groups composed of industry experts have provided their input. The test has three components: evidence of interest, evidence of financial impact, and forward impact adjustment.

The interest test has two components, a heat map score and an industry working group score. The heat map score is derived from a search for relevant keywords in documents stored on Bloomberg servers and indicates the relative importance of the issue among SASB's initial list of 43 generic sustainability issues. Evidence of interest is gathered by searching tens of thousands of industry-related documentsForm 10-Ks, shareholder resolutions, CSR reports, media and SEC comment letters-for key words related to 30 general sustainability issues. The industry working group score signals the percentage of industry working group members that found the issue to be material. SASB convenes an industry working group to provide feedback on the disclosure items and accounting metrics identified in the initial research phase. The industry working groups are composed of balanced representation from corporations, market participants, and public interest intermediaries. Primary industry working group feedback is collected via an online survey. After the conclusion of online survey, SASB's research team conducts outreach to industry working group members to gain additional insight.

The financial impact test uses a value framework developed by McKinsey and seeks to identify evidence of financial impact on revenues/costs, assets/liabilities, or cost of capital from the focal issue in an industry. Evidence of financial impact is gathered by examining sell side research, investor call transcripts, third party case studies, anecdotal evidence, and news articles. After identifying a minimum set of disclosure topics for an industry, for which there is solid evidence of both investor interest and financial impact, SASB identifies and documents existing metrics and practices used to account for performance on each disclosure topic. Any evidences found are publically disseminated through industry-specific industry briefs. 
The forward-looking impact test assesses the future probability and magnitude of financial impact from the focal issue to capture issues that may fail the financial impact test but may still be relevant for investors. The forward-looking impact test also assesses whether the issue will generate significant externalities in the future. However, it should be noted that to date the forward looking impact adjustment has been rarely used by SASB to switch a topic from immaterial to material. After the consultation with the industry working group has finished, SASB prepares an Exposure Draft Standard with accounting metrics and technical protocols for each of the disclosure topics.

In the next phase, SASB releases the Exposure Draft Standard for a 90 day public comment period. At this time, any member of the public can download the Exposure Draft Standard from SASB's website and provide feedback via a letter. At the conclusion of the public comment period, SASB incorporates feedback received into the standard. The Standards Council then reviews the standard to ensure consistency, completeness and accuracy. With the Standards Council's final review, the Provisional Standard is considered complete. The Provisional Sustainability Accounting Standard is then published and made available to the public. 


\section{Appendix III}

\section{Sector-level Materiality Map}

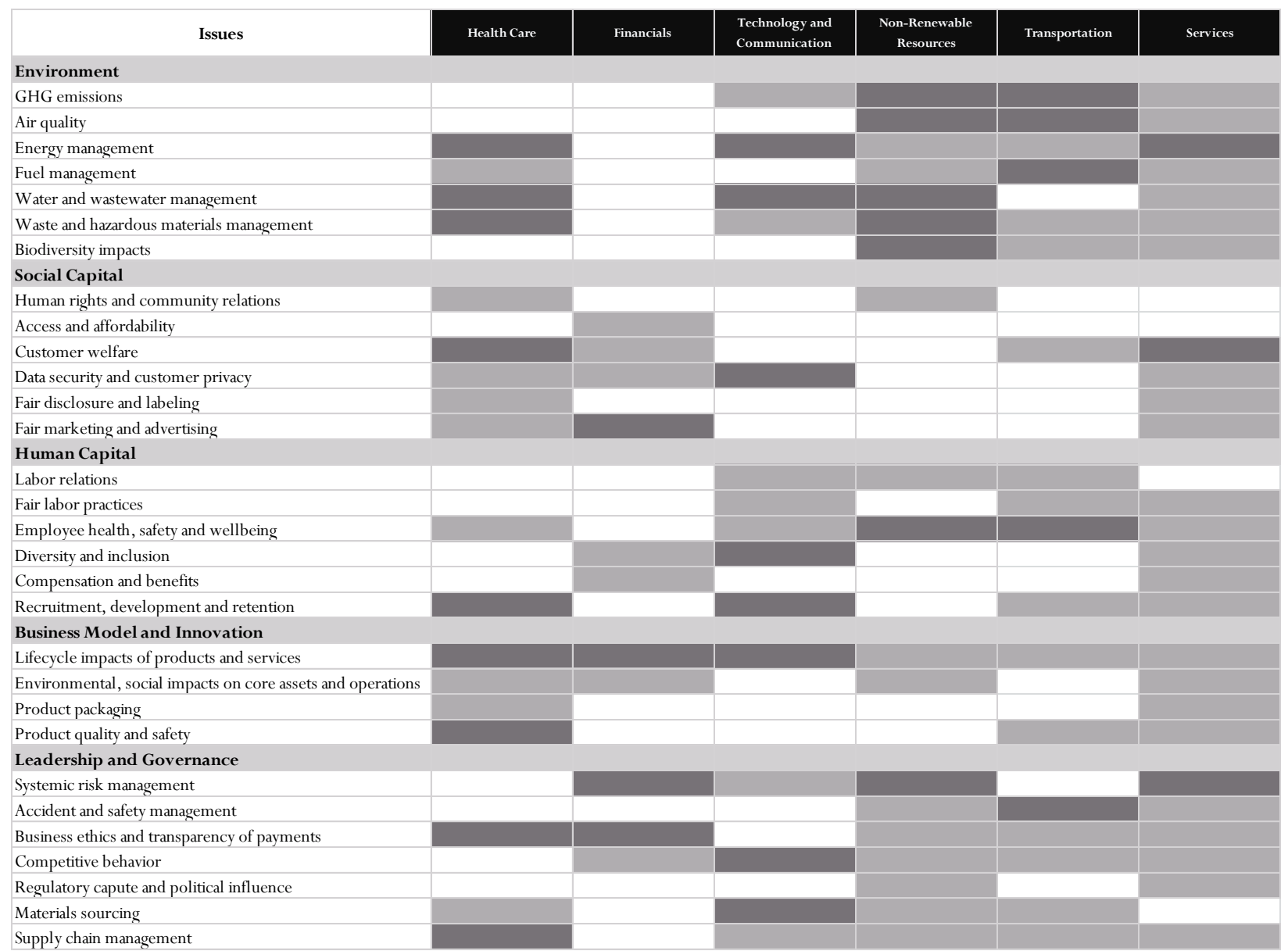

Source: Sustainability Accounting Standards Board. www.sasb.org

Note: Dark (light) grey color means that for more (less) than $50 \%$ of the industries within the sector the issue is material. White means that the issue is not material for any industry within the sector. To see materiality maps at the industry level visit www.sasb.org 